\author{
Костенко А.О., Пашко П.В.
}

\title{
РОЗБУДОВА СИСТЕМИ УПРАВЛІННЯ РИЗИКАМИ В ЧАСТИНІ ВІДБОРУ ПІДПРИЕМСТВ ДЛЯ ПРОВЕДЕННЯ МИТНОГО АУДИТУ В УКРАЇНІ
}

\begin{abstract}
У статті досліджено досвід передових держав у сфері управління ризиками та використання системи управління ризиками під час митного контролю після випуску товарів. Проведено порівняльний аналіз міжнародних стандартів, національного іноземного законодавства з вітчизняними законодавчими $i$ підзаконними актами та запропоновано внесення змін до них. Висвітлено механізм роботи та складові процесу відбору суб'єктів господарювання для митного контролю після випуску товарів. Запропоновано авторську систему критерїв ризику для відбору підприємств для проведення митного аудиту в Украӥні.
\end{abstract}

Ключові слова: ризик, критерії ризику, система управління ризиками, система відбору суб'єктів господарювання, митний аудит, контроль після випуску товарів, міжнародні стандарти, досвід іноземних краӥн.

Постановка проблеми. 3 метою блокування та упередження загроз митній безпеці України органи доходів i зборів, в межах своєї компетенції, зобов'язані використовувати найефективніші інструменти митного контролю. На думку авторів, нині завданням цих органів постає запровадження сучасної ефективної системи митного контролю після випуску товарів, який зосереджується на ризикових суб'єктах господарювання, та спрощення процедур міжнародної торгівлі для осіб, які працюють без порушення митних правил. Детермінантою функціонування такої системи $€$ автоматизований відбір об'єктів митного контролю після випуску товарів з використанням системи управління ризиками.

Аналіз останніх досліджень і публікацій. У напрямку дослідження теоретичних та прикладних аспектів управління ризиками в митній справі слід відзначити здобутки таких авторів як: П. Пашко, П. Пісной, С. Терещенко, Т.Савунова, А. Войцещук, А. Журавльова, Єлкин С.Є., Єлкина О.С., Попова Л.І. та інші [1, c.55-56; 2, с. $28 ; 3$, с. 117-118]. Проте питанню проблематики управління ризиками під час митного контролю після випуску товарів в Україні окрема увага не приділялась.

Формулювання цілей статті. Проаналізувати існуючі вітчизняні та іноземні механізми

( ) Костенко Аліса Олексіївна, молодший науковий співробітник, Науково-дослідний інститут фіскальної політики Університету державної фіскальної служби України, м. Ірпінь, тел.: 0958022295, email: a.kostenko306@gmail.com

Пашко Павло Володимирович, д.е.н., професор кафедри митної справи, Навчально-науковий інститут економіки, оподаткування та митної справи Університету державної фіскальної служби України, м. Ірпінь управління ризиками під час митного аудиту та запропонувати власну систему критеріїв відбору підприємств для проведення митного аудиту в Україні.

Опис основного матеріалу дослідження. Завданням системи управління ризиками в митниці $\epsilon$ створення сучасної ефективної системи митного контролю, виходячи 3 принципу вибірковості 3 метою спрощення процедур міжнародної торгівлі для осіб, які працюють без порушення митних правил, та проведення поглибленого дослідження ризикових осіб, а також оптимального розподілу ресурсів контролюючого органу, що, у свою чергу, сприятиме підвищенню рівня митної безпеки. Чітке уявлення про всю множину ризиків та взаємозв'язок між ними є важливою умовою мінімізації їх негативних наслідків та підвищення ефективності здійснення державної митної справи [1, с.14].

Необхідність застосування та вдосконалення митного контролю на основі аналізу ризиків регламентована ключовими міжнародними документами 3 митної справи. Стандартні правила Міжнародної конвенції про спрощення і гармонізацію митних процедур та Рамкові стандарти безпеки та полегшення всесвітньої торгівлі передбачають застосування системи управління ризиками при митному контролі, яка базується на сукупності засобів оцінки імовірності недотримання законодавства, 3 метою виявлення потенційно небезпечних товарів та транспортних засобів $[4,5]$. Стандартом 14 Митних прототипів передбачається проведення аудиту підприємств та операцій з високим рівнем ризику [6].

Стаття 7 Угоди про спрощення процедур торгівлі зобов'язує членів СОТ застосовувати систему управління ризиками 3 метою уникнення 
дискримінації або прихованих обмежень для міжнародної торгівлі [7].

Щодо досвіду та методик іноземних країн, то, наприклад, у Німеччині підприємства для проведення митного аудиту відбираються за допомогою автоматизованої системи управління ризиками. Така система існує окремо від системи управління ризиками, що використовується під час митного оформлення товарів. В подальшому відібраний список коригується співробітниками підрозділів митного аудиту 3 урахуванням актуальності тієї чи іншої перевірки. Загалом, щорічно митними аудиторами німецької митниці перевірки проводиться у відношенні 2-3\% підприємств, що знаходяться на обліку митниці.

У Литві використовується єдина система аналізу ризиків під час митного оформлення та митного аудиту. Система містить бальну шкалу «значимості» та «вірогідності» ризиків.

Аналогічні системи для відбору підприємств для проведення митного аудиту існують у інших країнах-членах ЄС.

Законодавством Російської Федерації також передбачено застосування системи управління ризиками у митному контролі після випуску товарів [8].

Як яскравий приклад роботи системи управління ризиками на високому рівні слід виділити систему Митної служби Грузії. 3 іï допомогою митні декларації автоматично розподіляються на чотири режими випуску вантажів: Зелений коридор (випуск без контролю), Синій коридор (випуск без контролю за умови подальшого проведення митного постаудиту), Жовтий коридор (документальний контроль), Червоний коридор (фізичний контроль). Система управління ризиками присвоює колір режиму автоматично, без особистісного фактора [9]. Таким чином, у даній системі усі критерії ризику знаходяться у єдиній базі та групуються за формами здійснення митного контролю.

Митний контроль після випуску товарів в Україні здійснюється підрозділами митного аудиту ДФС як одна 3 форм митного контролю проведення документальних перевірок дотримання вимог законодавства України 3 питань державної митної справи, у тому числі своєчасності, достовірності, повноти нарахування та сплати митних платежів (далі перевірка). На сьогодні підприємства до планових перевірок відбираються за 7 критеріями у відповідності до наказу Міністерства фінансів України від 02.06.2015 №524 [10]. За даними критеріями можуть відбиратися тисячі підприємств, що ставить під сумнів доцільність такого відбору взагалі.
Потребується розробка більш деталізованих індикаторів ризику та запровадження можливості постійного їх вдосконалення та розбудови в залежності від тенденцій у зовнішньоекономічних процесах.

У Митному кодексі України (далі - Кодекс) на думку автора питанню системи управління ризиками приділено недостатньо уваги. Регламентовано лише деякі аспекти діяльності 3 оцінки та управління ризиками (ст.ст.361-363). Реалізація спільного митного контролю обмежена та передбачена лише у пунктах пропуску через державний кордон України.

Порядок здійснення аналізу, оцінки та управління ризиками визначений наказом Міністерства фінансів України від 31.07.2015 № 684. При цьому, законодавство України не містить положень про розроблення і реалізацію заходів з управління ризиками під час митного аудиту та врахування результатів митного аудиту у системі управління ризиками. Хоча обов'язковість вибірковості митного контролю на підставі системи управління ризиками передбачена Кодексом (ст.320), зазначена норма не виконується належним чином у частині проведення перевірок. [11]. На даний час для відбору підприємств 3 метою проведення перевірок підрозділами митного аудиту ДФС можуть використовуватися лише ті критерії ризиків, які запрограмовані в АСАУР для спрацювання під час митного оформлення, оскільки окремих ризиків для відбору підприємств для проведення перевірок не розроблено. Тобто відсутні методологія та програмне забезпечення, за допомогою яких можливо в автоматичному режимі акумулювати інформацію щодо ризиків, які спрацювали під час митного оформлення товарів підприємства, виявлених порушень або підтвердження відсутності порушень, встановлених за результатами попередніх контрольноперевірочних заходів, виявлених іншими підрозділами або державними органами, результатів процедури оскарження.

Крім того, органами ДФС здійснюється обмін інформацією лише 3 іншими підрозділами ДФС та уповноваженими органами інших країн та не налагоджено партнерські відносини з суб'єктами зовнішньоекономічної діяльності, що є важливим інформаційним ресурсом під час формування ризиків.

Проведені дослідження виявили нагальну необхідність вдосконалення системи управління та впровадження багатоетапного аналізу ризиків в Україні.

Першим етапом даного процесу має стати внесення змін до законодавства. Необхідним $є$ 
доповнення ст. 363 Кодексу та визначення обов'язковості врахування результатів митного аудиту у системі управління ризиками, внесення до Кодексу статті, присвяченої роботі системи управління ризиками для митного аудиту та іiі взаємодії $з$ системою управління ризиками для митних оформлень. Слід розширити сферу роботи АСАУР та відповідного законодавства або створити окремі нормативно-правові акти та програмне забезпечення для роботи 3 індикаторами ризику для відбору об'єктів перевірок у рамках контролю після випуску товарів.

У зв'язку з зазначеним другим етапом має стати створення системи упраління ризиками, яка буде включати критерії та індикатори ризику для відбору підприємств 3 метою проведення перевірок.

За результатами, отриманими під час дослідження, проведеного аналізу міжнародного законодавства, національного законодавства та методик інших країн, пропонується авторська система критеріїв ризику для відбору підприємств для проведення митного аудиту (далі-Система).

За результатами проведеного дослідження у Системі було сформовано такі області аналізу митних ризиків: податкова історія, інформація із зовнішніх джерел, співставлення показників за митними платежами, митною вартістю, товаром, контрактом [складено з використанням 12, с.1-6].

Серед критеріїв ризику визначено у тому числі такі: результати попередніх перевірок за митним i податковим напрямами, відомості податкової звітності, інших документів, будь-яка інша інформація, у тому числі 3 відкритих джерел, що може свідчити про порушення митного законодавства, наявність протоколів про порушення митних правил, досудових розслідувань, справ про банкрутство, оперативно-розшукових справ, неподання податкової звітності протягом попередніх п'яти років, тривалість роботи підприємства менше одного року, перешкоджання роботі співробітників контролюючого органу під час попередніх перевірок, значна питома вага митних декларацій, що були відкликані, за якими було складено картку відмови, рішень про коригування митної вартості, імпорт товарів, які не могли бути вироблені задекларованим виробником чи у задекларованій країні, у митних деклараціях відсутні класифікаційні признаки для однозначної класифікації товарів за УКТ ЗЕД, при декларуванні товарів спрацьовував ризик недостовірності величин складових митної вартості або заповнення транспортного засобу, податкове навантаження на одиницю товару менше за середній показник для подібних товарів, платежі за зовнішньоекономічними договорами здійснюються через банки, розташовані на території, що має пільговий режим оподаткування.

Джерелами інформації для формування переліку ризиків визначено дані, зазначені в митних та податкових деклараціях, деклараціях митної вартості, базах даних ДФС, грошових, фінансових і бухгалтерських документах, звітах, контрактах, рахунках, облікових записах та інших документах, пов'язаних 3 товарами, відомості про які заявлені у митних деклараціях, отримані від суб'єктів господарювання, інших державних, недержавних, міжнародних, іноземних органів та установ, у тому числі в результаті виконання форм митного контролю під час перетину митного кордону або митного оформлення, такі, що знаходяться у відкритому доступі.

Систему пропонується використовувати для проведення як документальних планових перевірок, так i позапланових. 3 метою ранжування суб'єктів господарювання та виявлення найбільш ризикових пропонується використовувати 5-бальну систему оцінювання. При відборі пропонується враховувати показники за результатами діяльності підприємств за три попередні роки та обсяги постачання. Обов'язковою умовою функціонування Системи $€$ систематичне оновлення та доповнення існуючих та видалення неактуальних критеріїв ризику. Наприклад, група товарів, імпортерів, брокерів, галузь, вид діяльності можуть бути відбиратись як ризикові. Така оперативна інформація повинна отримуватись від профільних департаментів ДФС (Департаменту таргетингу, Департаменту організації митного контролю, Депатаменту адміністрування митних платежів, Депратаменту протидії митним правопорушенням). При формуванні критеріїв ризиків необхідним $\epsilon$ врахування пропозицій територіальних підрозділів ДФС та можливість встановлювати критерії у межах визначених регіонів.

Після генерування списку ризикових підприємств їх необхідно розподілити в залежності від кількості митних декларацій та обсягів постачання за категоріями 3 метою врахування як малих так і великих підприємств. Для створення такої шкали необхідно провести аналіз обсягів митних оформлень в Україні.

За результатами отриманих результатів про ризики, які спрацювали, орган доходів і зборів може приймати одне 3 таких рішень: проведення додаткового аналізу діяльності суб'єкта господарювання на предмет інших ризиків, 
опитування, запит документів у суб'єкта господарювання або його контрагентів; проведення планової документальної перевірки; проведення позапланової документальної перевірки у разі наявності ризику лише за окремими напрямами діяльності або операціями.

Висновки та перспективи подальших досліджень. Запровадження автоматизованої системи відбору суб'єктів зовнішньоекономічної діяльності для проведення митного контролю після випуску товарів на основі запропонованої системи критеріїв ризику дозволить значно підвищити ефективність перевірок шляхом підвищення вірогідності виявлення операцій, проведених з порушенням законодавства. У той же час, потребується розробка індикаторів ризику для визначених критеріїв у рамках подальших досліджень.

\section{ПЕРЕЛІК ВИКОРИСТАНИХ ДЖЕРЕЛ}

1. Управління ризиками в митній справі: зарубіжний досвід та вітчизняна практика : монографія; за заг. ред. І.Г. Бережнюка. - Хмельницький. : ПП. Мельник А.А., 2014. - 288 с.

2. Терещенко С.С. Правова основа формування системи аналізу ризиків як інструменту вдосконалення технології здійснення митних процедур / С.С. Терещенко, С.В. Галько // Митна безпека. - 2010. - №2. - С.2636.

3. Попова Л. И. Применение субъектно-ориентированного подхода при категорировании участников внешнеэкономической деятельности в рамках системы управления рисками / Л. И. Попова // Вестник Тюменского государственного университета. Социально-экономические и правовые исследования. - 2016. № 1. - С. 113-120.

4. Міжнародна конвенція про спрощення та гармонізацію митних процедур від 18.05.1973. - [Електронний pecypc]. - Режим доступу: http:// zakon.rada.gov.ua.

5. Рамкові стандарти забезпечення безпеки і спрощення процедур міжнародної торгівлі. - [Електронний pecypc]. - Режим доступу: http://ambu.org.ua/files/ram_standart.html.

6. Customs Blueprints, Pathways to modern customs. Luxembourg: Office for Official Publications of the European Communities, 2007. - [Електронний ресурс].

7. Протокол про внесення змін до Марракеської угоди про заснування Світової організації торгівлі від 27.11.2014. - [Електронний ресурс]. - Режим доступу: http:// zakon.rada.gov.ua.

8. Приказ Федеральной таможенной службы от 06.07.2012 № 1372 «Об утверждении Инструкции о действиях должностных лиц таможенных органов при взаимодействии подразделений таможенного контроля после выпуска товаров и структурных подразделений таможенных органов при организации таможенного контроля после выпуска товаров» . - [Електронний ресурс]. - Режим доступу: www.consultant.ru.

9. Портал логістики Казахстану. - [Електронний ресурс]. - Режим доступу: http://portal.kazlogistics.kz.

10. Наказ Міністерства фінансів України від 02.06.2015 №524 «Про затвердження Порядку формування плану-графіка проведення документальних планових перевірок платників податків». - [Електронний ресурс]. Режим доступу: http:// zakon.rada.gov.ua.

11. Наказ Міністерства фінансів України від 31.07.2015 № 684 «Про затвердження Порядку здійснення аналізу та оцінки ризиків, розроблення і реалізації заходів з управління ризиками для визначення форм та обсягів митного контролю». - [Електронний ресурс]. - Режим доступу: http:// zakon.rada.gov.ua.

12. Лист Державної фіскальної служби України від 21.09.2017 № 12427/Ш/99-99-14-04-02-14.

\section{REFERENCES}

1. Berezhnyuk, I. (2014). Upravlinnja ryzykamy v mytnij spravi: zarubizhnyj dosvid ta vitchyznjana praktyka [Risk management in customs: foreign experience and domestic practice]. - Khmelnytskyi: PP Melnik AA [in Ukrainian].

2. Tereschenko, S., Galko, S. (2010). Pravova osnova formuvannja systemy analizu ryzykiv jak instrumentu vdoskonalennja tehnologii' zdijsnennja mytnyh procedur [The legal basis for the formation of a risk analysis system as an instrument for improving the technology of customs procedures implementation]. Mytna bezpeka - Customs security, 2, 26-36 [in Ukrainian].

3. Popova, L. (2016) rimenenie subektno-orientirovannogo podhoda pri kategorirovanii uchastnikov vneshnejekonomicheskoj dejatel'nosti $\mathrm{v}$ ramkah sistemy upravlenija riskami [Application of the subject-oriented approach in the categorization of participants in foreign economic activities within the framework of the risk management system]. Visnyk Tiumenskoho derzhavnoho universytetu - Bulletin of the Tyumen State University, 1, 113-120 [in Russian].

4. International Convention on the simplification and harmonization of customs procedures of 18.05.1973. Retrieved from: http://zakon.rada.gov.ua.

5. Framework standards for security and facilitation of international trade procedures. (2005) - Retrieved from: http://ambu.org.ua/files/ram_standart.html.

6. Customs Blueprints, Pathways to Modern Customs (2007). Luxembourg: Office for Official Publications of the European Communities.

7. Protokol pro vnesennja zmin do Marrakes'koi' ugody pro zasnuvannja Svitovoi' organizacii' torgivli vid 
27.11.2014 [Protocol amending the Marrakech Agreement Establishing the World Trade Organization from 27.11.2014]. (2014). zakon.rada.gov.ua. Retrieved from: http://zakon5.rada.gov.ua/laws/show/981_053 [in Ukrainian].

8. Ob utverzhdenii Instrukcii o dejstvijah dolzhnostnyh lic tamozhennyh organov pri vzaimodejstvii podrazdelenij tamozhennogo kontrolja posle vypuska tovarov i strukturnyh podrazdelenij tamozhennyh organov pri organizacii tamozhennogo kontrolja posle vypuska tovarov ot of 06.07.2012 № 1372 [On approval of the Instruction on the actions of officials of customs authorities in the interaction of customs control units after the release of goods and structural units of the customs authorities in the organization of customs control after the release of goods of 06.07.2012 № 1372]. (2012). Retrieved from: http://www.consultant.ru [in Russian].

9. Logistics Portal of Kazakhstan. portal.kazlogistics.kz. Retrieved October 1, 2017, from http://portal.kazlogistics.kz.

10. Pro zatverdzhennja Porjadku formuvannja planu-grafika provedennja dokumental'nyh planovyh perevirok platnykiv podatkiv vid 02.06.2015 № 524 [On Approval of the Procedure for Formulating a Plan-Schedule for Documentary Planned Inspections of Taxpayers of 02.06.2015 № 524]. (2015). Retrieved from: http://zakon3.rada.gov.ua/laws/show/z0751-15 [in Ukrainian].

11. Pro zatverdzhennja Porjadku zdijsnennja analizu ta ocinky ryzykiv, rozroblennja i realizacii' zahodiv z upravlinnja ryzykamy dlja vyznachennja form ta obsjagiv mytnogo kontrolju vid 31.07.2015 № 684 [On Approval of the Procedure for the Analysis and Evaluation of Risks, Development and Implementation of Risk Management Measures for the Determination of Forms and Amounts of Customs Controls of 31.07.2015 № 684]. (2015). Retrieved from: http://zakon.rada.gov.ua [in Ukrainian].

12. State Fiscal service of Ukraine (2017). Letter of 21.09.2017 N 12427/Sh/99-99-14-04-02-14 [in Ukrainian].

Одержано 15.03.2018 p. 